\title{
Gender Equity and Economic Empowerment: Women and Ethical/Religious Family Law in Bangladesh
} Prof Dr Taslima Monsoor, Professor, Dept. of Law, Dhaka University

Email: taslima_monsoor@hotmail.com

Women suffer the denial of land and property rights in Bangladesh. They are severely restricted to acquire property although they have the ability. The core of the problem is that many women in Bangladesh today are deprived of the rights granted by the ethical/religious and statutory family laws. Prominently, women are deprived of their rights of inheritance, maintenance and dower. The study of gender and property rights under Islamic and ethical law is a complicated one, which has been hardly explored; an attempt is however, made in this article.

The Constitution of Bangladesh gives gender equality but the Personal Laws give gender equity, then how can the Personal Laws exist? First, article 149 states that all existing laws shall continue to have effect, second, the constitutional clause of sexual equality [under article 28(2)] only applies to the public sphere third, article 28(1) provides freedom of religion. Finally, the directive principles of state policy, gives preference to Islam as state religion. Thus, the Constitution itself protects Religio-Personal Laws.

The primacy given to custom has worked to the detriment of Muslim women and a shift to ethical and religious Sharia law of property and succession would be a positive step. In a legal project, it seems appropriate to conclude that a better-sensitised judiciary could empower and protect women from economic deprivation. 